\title{
A $5-\mathrm{HT}_{1}$-like receptor mediates a pertussis toxin-sensitive inhibition of rat ventromedial hypothalamic neurones in vitro
}

\author{
${ }^{1}$ Nigel R. Newberry \& Tony Priestley \\ Merck Sharp and Dohme Research Laboratories, Neuroscience Research Centre, Terlings Park, Eastwick \\ Road, Harlow, Essex, CM20 2QR
}

\begin{abstract}
5-Hydroxytryptamine (5-HT), 5-carboxamidotryptamine and 8-hydroxy-2-(di-n-propylamino)-tetralin inhibited rat ventromedial hypothalamic neurones in vitro in a concentration-dependent manner. The agonist-induced inhibition was reduced by spiperone $(1 \mu \mathrm{M})$ and by pertussis toxin, but not by MDL 72222 $(10 \mu \mathrm{M})$ or ketanserin $(1 \mu \mathrm{M})$. The inhibition appeared to be mediated via 5 -HT $1 \mathrm{H}_{1 \mathrm{r}}$-receptors and a pertussis toxin-sensitive pathway.
\end{abstract}

Introduction Both the ventromedial hypothalamus (VMH) and 5-hydroxytryptamine (5-HT) have been implicated in the control of food intake (Blundell, 1977; Shimizu et al., 1987). Indeed, the VMH is densely innervated by mesencephalic 5-HT containing neurones (Willoughby \& Blessing, 1987). Despite these links, little is known of the electrophysiology, pharmacology and possible biochemical mediators of 5-HT actions on VMH neurones. We have initiated a combined study of the above in a slice preparation of the rat VMH.

Methods Male Sprague-Dawley rats (Bantin \& Kingman), $80-150 \mathrm{~g}$, were killed by decapitation and their brains removed. Coronal slices $(350 \mu \mathrm{m}$ thick) of the mediobasal hypothalamus were cut with an Oxford Vibratome. Each slice was submerged (bath volume $\simeq 0.5 \mathrm{ml})$ and perfused $\left(2 \mathrm{ml} \mathrm{min}^{-1}\right)$ with medium $\left(30^{\circ} \mathrm{C}\right.$, equilibrated with $5 \% \mathrm{CO}_{2}$ in $\left.\mathrm{O}_{2}\right)$ containing (mM): $\mathrm{NaCl} 125, \mathrm{KCl} 2, \mathrm{KH}_{2} \mathrm{PO}_{4} 1$, $\mathrm{CaCl}_{2} 2.5, \mathrm{MgSO}_{4} 1, \mathrm{NaHCO}_{3} 25$ and dextrose 10 .

The excitatory amino acid quisqualate $(1 \mu \mathrm{M}$, Cambridge Research Biochemicals) was routinely included in the medium to increase and stabilise cell firing rate. Extracellular spikes (e.g. Figure 1d) of unitary amplitude were recorded from the ventromedial hypothalamus with glass microelectrodes (filled with the above medium, tip diameter $1-10 \mu \mathrm{m}$ )

\footnotetext{
${ }^{1}$ Author for correspondence.
}

and their digitised firing rate monitored on a chart recorder.

Agonists were applied for $1 \mathrm{~min}$, since the effect of 5-HT and 5-carboxamidotryptamine (5-CT) peaked in this time, and the concentration required to inhibit the firing rate by $50 \%\left(\mathrm{IC}_{50}\right)$ was determined. Antagonists were superfused for $30 \mathrm{~min}$ before redetermining the $\mathrm{IC}_{50}$ of an agonist. Each value refers to a different cell from a different rat unless otherwise stated.

Pertussis toxin (1.5 $\mu \mathrm{g}$ in $5 \mu \mathrm{l}$, Porton Products) or vehicle alone $(50 \%$ glycerol, $50 \%$ phosphate buffer) was injected into the third ventricle, under equithesin $\left(4 \mathrm{ml} \mathrm{kg}^{-1}\right.$, i.p.) anaesthesia, three to five days before the rats were killed.

Results The firing rate of ventromedial hypothalamic neurones, excited by quisqualate, was inhibited by 5-HT in a concentration-dependent manner (Figure 1a). The mean $\mathrm{IC}_{50}$ for 5-HT was $2.5 \mu \mathrm{M}$, (range $=1-5 \mu \mathrm{M}, n=7$ ). The inhibition to $10 \mu \mathrm{M} 5$-HT was followed by a clear excitation ( 20 to $90 \%$ control) on 6 of 13 neurones (Figure 1a). The 5-HT-induced inhibition was also apparent in the absence of quisqualate on 3 spontaneously firing cells (in medium containing $6 \mathrm{mM} \mathrm{K}^{+}$). We have preliminary evidence from intracellular recordings indicating that 5-HT $(10 \mu \mathrm{M})$ hyperpolarizes VMH neurones ( $n=4$, data not shown).

The selective 5-HT ${ }_{1}$ ligands 5-CT (Graham Showell, MSD) and 8-hydroxy-2-(di-n-propylamino)tetralin (8-OH-DPAT, Research Biochemicals Incorporated) also inhibited these cells (Figure 1b). Mean $\mathrm{IC}_{50}$ values were $0.018 \mu \mathrm{M}$, (range $=0.004$ $0.026, n=8$ ) for 5-CT and $0.54 \mu \mathrm{M}$, (range $=0.1-1.0$, $n=5$ ) for 8-OH-DPAT. For each agonist, a ten fold higher concentration than the IC $_{50}$ completely inhibited spike firing. Unlike 5-HT, the inhibitions by 5-CT and 8-OH-DPAT were not followed by excitations. The inhibitions induced by 8-OH-DPAT were particularly prolonged.

5-CT was chosen for the antagonist studies since it gave the simplest, shortest response. Neither 


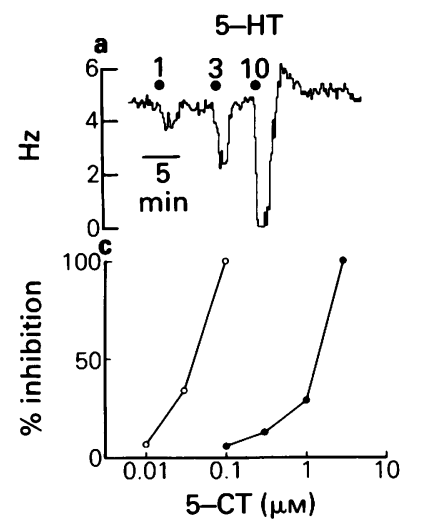

b $\quad 5-\mathrm{CT}$

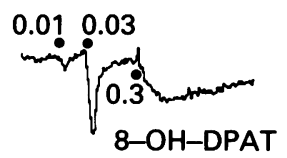

d
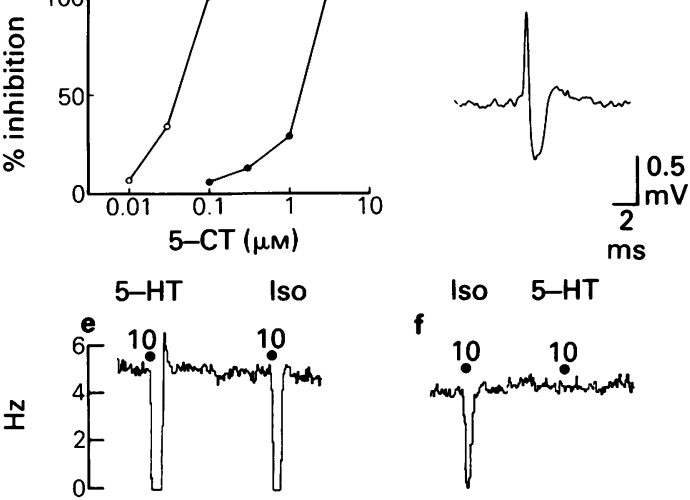

Figure 1 The pharmacology and pertussis toxin-sensitivity of the 5-hydroxytryptamine (5-HT)induced inhibition of rat ventromedial hypothalamic neurones in vitro. (a) Concentration-dependent inhibition of a neurone by 5-HT (applied during filled circle), (b) 5-carboxamidotryptamine (5-CT) and 8-hydroxy-2-(di-n-propylamino)-tetralin (8-OH-DPAT) also inhibit these neurones, (c) graph of effect of spiperone $(O)$ on the 5-CT induced $(O)$ inhibition of a single cell, (d) a representative extracellular spike. A comparison of the effects of isoguvacine and 5-HT in a vehicle-injected (e) and a pertussis toxin-treated (f) animal are shown. All concentrations of applied drugs in $\mu \mathrm{M}$. Quisqualate $(1 \mu \mathrm{M})$ present in each different experiment. The time calibration for (b) (e) and (f) is the same as in (a). The firing rate scales for (b) and (f) are the same as those in (a) and (e), respectively.

$1 \alpha \mathrm{H}, 3 \alpha, 5 \alpha \mathrm{H}$-tropan-3-yl-3,5-dichlorobenzoate (MDL $72222,10 \mu \mathrm{M}$, Merrell Dow), a 5-HT 3 antagonist, nor ketanserin $\left(1 \mu \mathrm{M}\right.$, Janssen), a $5-\mathrm{HT}_{2}$ antagonist, reduced the 5-CT-induced inhibition; when superfused together the dose-ratios were 0.5-1.0 $(n=3)$. The effect of 5-CT was, however, antagonized by $1 \mu \mathrm{M}$ spiperone (Janssen, $n=3$, e.g. Figure 1c); dose-ratios at the $\mathrm{IC}_{50}$ level gave calculated $\mathrm{pA}_{2}$ values $\left(\mathrm{pA}_{2}=\log (\right.$ dose-ratio - $)$ $-\log$ [antagonist concentration]) of 7.5, 7.6 and 7.9. None of these antagonists induced a detectable change in firing rate when superfused alone.

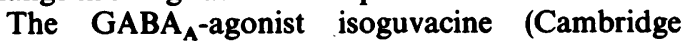
Research Biochemicals) routinely inhibited these neurones with a threshold concentration of $1 \mu \mathrm{M}$. We compared the inhibitory actions of isoguvacine $(10 \mu \mathrm{M})$ and 5 -HT $(10 \mu \mathrm{M})$ on cells in slices from 5 vehicle-injected and 6 pertussis toxin-treated animals. In the vehicle-injected animals, 5-HT and isoguvacine inhibited firing (median (range, $n$ )) by $100 \%(35-100,10)$ and $100 \%(22-100,12)$, respectively. These effects were not significantly different from those in uninjected animals: $5-\mathrm{HT}=100 \%$ $(28-100,12)$, isoguvacine $=100 \%(80-100,6)$. In contrast, in pertussis toxin-treated animals the 5-HT induced inhibition was reduced to $0 \%(0-11,8)$ but isoguvacine still inhibited by $100 \%(60-100 \%, 7)$ (cf. Figure 1e with Figure 1f). In the pertussis toxintreated animals a pure excitation to 5-HT $(12-270 \%$, median $=18$ ) was seen on 5 out of 8 cells (not shown).

The firing rates $(\mathrm{Hz}$; mean \pm s.d., $n)$ of the neurones in the three groups of animals were not significantly different, (uninjected $=5.3 \pm 1.7,36$; vehicle-injected $=5.9 \pm 1.6,13$; pertussis $=5.1 \pm$ $1.9,9)$.

Discussion The principal finding of these experiments is that 5-HT can inhibit ventromedial hypothalamic neurones in vitro. Although we cannot infer from the present experiments whether this effect was mediated by a direct effect on the recorded neurone, we can suggest that the effect was mediated by 5-HT ${ }_{1}$-like receptors since it was resistant to 5-HT and 5-HT ${ }_{3}$ antagonists (Bradley et al., 1986). Furthermore, the similarity of action of the 5-HT ligands 5-CT and 8-OH-DPAT and the high antagonist potency of spiperone indicated that the response was mediated by $5-\mathrm{HT}_{1 \mathrm{~A}}$-receptors (Middlemiss \& Fozard, 1983; Hoyer et al., 1985). It is interesting to note that this conclusion is supported by the presence of 5-HT 1 binding sites in this region (Vergé et al., 1986). The pharmacology of this response is similar to that of the 5-HT-induced hyperpolarization of the rat superior cervical ganglion (Gilbert \& Newberry, 1987).

The sensitivity of the 5-HT-induced inhibition to pertussis toxin suggests that the response is coupled to a $\mathbf{G}$ protein, possibly $\mathbf{G}_{\mathbf{i}}$ or $\mathbf{G}_{\mathbf{0}}$ (Sternweis \& Robishaw, 1984), indicating a similarity between this response and the hyperpolarization of CA1 pyramidal cells (Andrade et al., 1986). The pharmacology of the excitatory response to 5-HT on these VMH neurones has not been explored but it did not appear to involve a pertussis toxin-sensitive intermediate. As expected, it can also be concluded that the inhibition

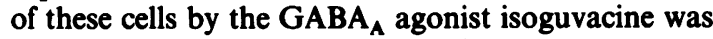
not mediated by such an intermediate.

Our results suggest that the inhibition of ventromedial hypothalamic neurones by 5-HT and related compounds was mediated by a $5-\mathrm{HT}_{1 \mathrm{~A}}$-receptor and a pertussis toxin-sensitive substrate. 


\section{References}

ANDRADE, R., MALENKA, R.C. \& NICOLL, R.A. (1986). A G protein couples serotonin and GABA $_{B}$ receptors to the same channels in hippocampus. Science, 234, 12611265.

BLUNDELL, J.E. (1977). Is there a role for serotonin (5hydroxytrypamine) in feeding? Int. J. Obes., 1, 15-42.

BRADLEY, P.B., ENGEL, G., FENIUK, W., FOZARD, J.R., HUMPHREY, P.P.A., MIDDLEMISS, D.N., MYLECHARANE, E.J., RICHARDSON, B.P. \& SAXENA, P.R. (1986). Proposals for the classification and nomenclature of functional receptors for 5-hydroxytryptamine. Neuropharmacology, 25, 563-576.

GILBERT, M.J. \& NEWBERRY, N.R. (1987). A 5-HT -like $^{-}$ receptor mediates a sympathetic ganglionic hyperpolarisation. Eur. J. Pharmacol., 144, 385-388.

HOYER, D., ENGEL, G. \& KALKMAN, H.O. (1985). Molecular pharmacology of $5-\mathrm{HT}_{1}$ and $5-\mathrm{HT}_{2}$ recognition sites in rat and pig brain membranes: radioligand binding studies with $\left[{ }^{3} \mathrm{H}\right] 5-\mathrm{HT},\left[{ }^{3} \mathrm{H}\right] 8-\mathrm{OH}-\mathrm{DPAT}$, $(-)\left[{ }^{125} \mathrm{I}\right]$ iodocyanopindolol, $\left[{ }^{3} \mathrm{H}\right]$ mesulergine and $\left[{ }^{3}\right.$ H] ketanserin. Eur. J. Pharmacol., 118, 13-23.

MIDDLEMISS, D.N. \& FOZARD, J.R. (1983). 8-Hydroxy-2(di-n-propylamino)-tetralin discriminates between sub- types of the 5-HT 1 recognition site. Eur. J. Pharmacol., 90, 151-153.

SHIMIZU, N., OOMURA, Y., PlATA-SAlamaN, C.R. \& MORIMOTO, M. (1987). Hyperphagia and obesity in rats with bilateral ibotenic acid-induced lesions of the ventromedial hypothalamic nucleus. Brain Res., 416, 153156.

STERNWEIS, P.C. \& ROBISHAW, J.D. (1984). Isolation of two proteins with high affinity for guanine nucleotides from membranes of bovine brain. J. Biol. Chem., 259, 1380613813.

VERGÉ, D., DAVAL, G., MARCINKIEWICZ, A., PATEY, A., EL MESTIKAWY, S., GOZLAN, H. \& HAMON, M. (1986). Quantitative autoradiography of multiple 5-HT $\mathrm{H}_{1}$ receptor subtypes in the brain of control or 5,7dihydroxytryptamine-treated rats. J. Neurosci., 6, 3474 3482.

WILLOUGHBY, J.O. \& BLESSING, W.W. (1987). Origin of serotonin innervation of the arcuate and ventromedial hypothalamic region. Brain Res., 418, 170-173.

(Received May 10, 1988 Accepted May 31, 1988) 